\title{
Expectations of Male and Female Adoptive Parents of Different Marital Status and Sexual Orientation
}

\author{
Sara L. Sohr-Preston ${ }^{1}$, Holly Kliebert ${ }^{1}$, Olivia Moreno ${ }^{1}$, Timothy Dugas ${ }^{1} \&$ Dylan Zepeda $^{1}$ \\ ${ }^{1}$ Department of Psychology, Southeastern Louisiana University, Hammond, LA, USA \\ Correspondence: Sara L. Sohr-Preston, P.O. Box 10831, Hammond, LA, 70402, USA. Tel: 1-985-549-5536. \\ E-mail: sara.sohr-preston@selu.edu
}

Received: August 14, 2017

Accepted: August 24, $2017 \quad$ Online Published: August 24, 2017

doi:10.5539/ijps.v9n3p92

URL: http://doi.org/10.5539/ijps.v9n3p92

\begin{abstract}
Adults in the U.S. (undergraduate college students and adults recruited online) read vignettes about a fictional individual seeking to adopt an infant. Based on random assignment, participants read versions in which the prospective adoptive parent described was either an implied male or female and single, married to someone of the opposite sex, or married to someone of the same sex. After reading the vignettes, participants rated their expectations of the prospective parent's ability to parent and their perceptions of the prospective parent's personal characteristics. Female participants reported significantly $(p<.05)$ higher expectations of general ability to parent and perceived higher responsibility, greater likeability, and less selfishness. Both sexes endorsed significantly lower anticipation of ability to parent and less responsibility when the prospective parent was designated as single or in a same-sex marriage. Same-sex prospective parents were additionally rated as significantly higher in immorality. Prospective fathers were rated as less likeable than prospective mothers and participants approved less of their plan to adopt. The authors discuss findings as relevant to bias favoring traditional families headed by a man and a woman with the wife taking the lead in the transition to parenthood.
\end{abstract}

Keywords: adoption, prejudice, single parents, same-sex parents, vignettes

\section{Introduction}

\subsection{Adoption as a Difficult Path to Parenthood}

The act of adoption involves an adult formally becoming a child's legal guardian and subsequently gaining the rights and responsibilities of a parent ("Adoption", 2016), thus forming a family based on a legal and social bond in place of a biological bond (Raleigh, 2012). The most recent U.S. Census indicated that approximately two percent of children under 18 were adopted (Kreider \& Lofquist, 2010). Adoption makes it possible for adults to become parents despite infertility, concerns over genetic heritage, or lack of an opposite-sex partner for single adults and same-sex couples. Single adults may adopt in any state so long as they meet other criteria for adoptions specified by a state (Child Welfare Information Gateway, 2012). Further, when a federal judge voided a Mississippi ban on adoptions by same-sex couples in 2016, it became legal in all fifty states for sexual minority individuals to adopt (Barbash, 2016). Becoming an adoptive parent, however, is in numerous ways much more difficult than the public believes. Specific laws vary from state to state, and not all states allow same-sex couples to adopt as joint parents (LifeLong Adoptions, 2017). In addition, adoptions generally involve exorbitant fees $(\$ 32,000-\$ 42,300$, on average for domestic infant adoption; $\$ 31,000-\$ 45,000$, on average, for international adoption, The National Infertility \& Adoption Education Nonprofit, 2015), time investment and uncertainty (Daniluk \& Hurtig-Mitchell, 2003), social stigmas often faced by adoptive parents as not "real" parents (Fisher, 2003; Miall, 1987), and covert bias against some prospective adoptive parents as not "ideal" applicants (Perrin \& the Committee on Psychosocial Aspects of Child and Family Health, 2002). That is, adoption is often an arduous and unpredictable process during which prospective parents are scrutinized in a manner biological parents typically are not. The fact that becoming an adoptive parent requires subjective approval by others (possibly including birth parents in addition to adoption agency personnel; Berry, Barth, \& Needell, 1996) renders it imperative to understand and ideally minimize any potential bias against prospective adoptive parents. The purpose of the current investigation was to examine such potential bias regarding adoption as a path to parenthood for individuals who are male, unmarried, or in a same-sex marriage. We summarize reasons for focusing on these particular groups of adults as possible targets of prejudice or bias below. 


\subsection{Marital Status}

Perceptions of a legitimate family encompassing only the so-called "traditional" family, consisting of a man, his wife, and their biological offspring (Andersen, 1991; Ethics Committee of the American Society for Reproductive Medicine, 2013; Robinson, 1997; Wegar, 2000) may shape individuals' attitudes toward potential adoptive parents. Because of this widespread notion, some may covertly or overtly anticipate that a prospective parent would be married even though single parents do indeed rear children. Attitudes toward single prospective adoptive parents may further reflect beliefs that single parenthood is a situation not normally entered willingly (Jeter, 1995; Monama, 2009). While many single parents become so because of unplanned pregnancy, partner death, relationship dissolution, or abandonment, there has been evident rise in the number of adults actively choosing to become a parent without a partner (Jadva, Badger, Morrissette, \& Golombok, 2009). Despite increases in intentional single parenthood, sometimes through adoption, stereotypes persist that single mothers are inherently inferior to married mothers (Bennett \& Jamieson, 1999; Robinson, 1997). Evidence suggests the general public and adoption agencies appear to consider single adults as appropriate adoptive parents only when the child is older or otherwise very difficult to place (Shireman, 1994).

Based on available statistics, most single adoptive parents are female (Children of All Nations, 2016; Groze, 1991). Although single men do adopt, there is considerably more research on the experiences of single mothers compared to single fathers. There is notable evidence suggesting single mothers as a group are in numerous ways at a disadvantage when compared to their married peers. For instance, single mothers in the U.S. seem less happy compared to other adults (Ifcher \& Zarghamee, 2014). In addition, children reared by single mothers display increased rates of an assortment of psychological problems such as hyperactivity, problematic peer relations, conduct disorder, and emotional problems (Dunn et al., 1998), poor quality adolescent mental health (Williams, Sassler, Frech, Addo, \& Cooksey, 2013), elevated school drop-out rates, and higher probability of teenage pregnancy (McLanahan \& Sandefur, 1994). Available evidence further indicates single mothers to be less involved in their children's primary school education (Ressler, Smith, Cavanagh, \& Crosnoe, 2017). One must interpret such findings in context, as many are somewhat dated and they stem from studies not distinguishing single mothers by choice from single mothers by circumstance. Supported negative consequences and correlates of single motherhood have been attributed to situational factors including low income and lack of social support (Jadva et al., 2009), aspects not necessarily present for adults adopting to achieve single parenthood by choice. In fact, single mothers by choice appear better educated and possess higher occupational prestige when compared to married peers (Pakizegi, 1990), and are generally highly educated and over 30 (Golombok, Zadeh, Imrie, Smith, \& Freeman, 2016). Studies comparing adopted children reared by single parents to their peers raised by partnered parents indicate no difference in rates of internalizing and externalizing behavior problems (Tan, 2004). Still, individuals exposed to overall findings depicting single parents as somehow inferior to partnered parents may hold bias in favor of prospective adoptive parents with spouses. Based on this evidence, we hypothesized that single prospective adoptive parents would be evaluated less favorably than married prospective adoptive parents.

\subsection{Same-Sex Couples}

Addressing potential bias favoring married parents necessitates recognition that, in the U.S. and other countries, marriage no longer exclusively refers to a legal union between a man and a woman. Even prior to the U.S. Supreme Court's legalization of same-sex marriage nationwide in 2015, the most recent U.S. Census indicated 131,729 same-sex, married-couple households (United States Census Bureau, 2011), and nearly two million children are being raised by gay and lesbian parents (Perrin, 2013).

Until rather recently, same-sex couples with children tended to raise offspring conceived within a previous opposite-sex marriage or romantic relationship (Markus, Weingarten, Duplessi, \& Jones, 2010). However, according to one report, approximately two million gay men and lesbians are interested in becoming parents through adoption (Gates, Badgett, Macomber, \& Chambers, 2007). Progressing from interest in adoption to successful adoption may be difficult for a variety of reasons, one of them involving legal restrictions in certain states. While all fifty states now allow an individual member of a same-sex couple to adopt, some states prohibit same-sex couples from adopting jointly or simply fail to explicitly address the practice in their laws (LifeLong Adoptions, 2016).

There are indications of continuing prejudice against same-sex parents, even when they are legally married, as evidenced when married foster mothers Beckie Peirce's and April Hoagland's foster daughter was taken from their home by a judge feeling the child would fare better with an opposite-sex couple (Moyer, 2015). Previous research has further documented that same-sex couples report a dearth of support from those in their social 
convoy regarding intent to become parents (Brown, Smalling, Groza, \& Ryan, 2009), encounter lengthier waiting periods while seeking adoption (Goldberg, Downing, \& Sauck, 2007), face intrusive or extraneous questioning during screening (Ross, Epstein, Anderson, \& Eady, 2009), are often examined more rigorously by adoption staff and generally held to an elevated standard (Brodzinsky \& the staff of the Evan B. Donaldson Adoption Institute, 2003; Ryan, Pearlmutter, \& Groza, 2004), and are frequently restricted to adopting difficult-to-place children (i.e., older children, siblings to be adopted together, or children with special needs; Ross et al., 2009). Even in geographic regions considered highly progressive, such as Ontario, Canada, adoption workers do not universally recognize potential parenting strengths of same-sex couples and many prioritize a heterosexual nuclear family model even when supporting same-sex adoption (Ross et al., 2009).

Latent bias against same-sex prospective adoptive parents may be embedded in worries over the capability of same-sex parents to offer sufficient quality of life for children, even though same-sex couples adopting children tend to be older, more educated, and possess greater economic resources than other adoptive parents (Gates et al., 2007). While considerably less research has targeted children of same-sex parents compared to those raised by opposite-sex parents, potentially due to challenges in finding samples of families headed by same-sex parents (Tasker, 2005), evidence indicates extensive similarity in quality of life and personal adjustment of both groups (Adams \& Light, 2015; Anderssen, Amlie, \& Ytterøy, 2002; Gartrell, Deck, Rodas, Peyser, \& Banks, 2005; Meezan \& Rauch, 2005; Patterson, 2006; Stacey \& Biblarz, 2001; Wainright \& Patterson, 2006). While a few supported differences have been reported, including harsher disagreements between lesbian mothers and their children compared to mothers raising a child with a father (see MacCallum \& Golombok, 2004), evidence also supports that same-sex parents offer, in noteworthy ways, greater quality of life than families headed by opposite-sex parents. For instance, planned lesbian-led families (i.e., involving children not from a previous heterosexual relationship) may entail less corporal punishment and more imaginative and domestic play than families led by opposite-sex parents (Golombok et al., 2003). Furthermore, children perceive closer relationships with their mothers when in families led by a single or partnered lesbian mother compared to opposite-sex, two-parent families (Golombok, Tasker, \& Murray, 1997). In addition, nonbiological mothers in dual-parent, lesbian-headed families seem more involved in child rearing (Tasker \& Golombok, 1998; Vanfraussen, Ponjaert-Kristoffersen, \& Brewaeys, 2003), more eager to parent children (Bos, van Balen, \& van den Boom, 2007), and more invested as a caregiver (Bos et al., 2007) than fathers in dual-parent heterosexual family units. Finally, reviews, while possessing limitations from difficulties in isolating core variables, do not support that children must be raised by both a mother and a father to achieve healthy development (Biblarz \& Stacey, 2010).

Despite such evidence that same-sex parents are as competent as opposite-sex parents in providing a supportive home environment contributing to healthy adjustment in offspring, general and widespread attitudes and beliefs persist that being reared by same-sex parents would necessarily adversely impact children's development (Pennington \& Knight, 2011). This may stem from concerns over lack of a male or female role model (Robinson, 1997). The evidence for such concerns prompted our second hypothesis that attitudes toward married prospective parents pursuing adoption would be less positive when the marriage is between two women or two men in contrast to a marriage between a man and a woman. Because previous research suggests male university students are more probable than female students to view homosexuality as a choice and to consider parents' homosexual relations to be harmful to children's development (Costa et al., 2014) and women seem more supportive of same-sex couples adopting children than men (McCrary, 2014), participants' reported sex was controlled for when examining hypotheses.

\subsection{Parent Sex}

Prospective adoptive parents seeking to become single parents or same-sex parents may be viewed differently based on whether they are to become mothers versus fathers. According to the most recent U.S. census, about 1.96 million households were headed by single fathers, and almost 10.32 million households were headed by single mothers (Vespa, Lewis, \& Kreider, 2013). Single mothers may be more harshly evaluated than single fathers, with evidence indicating single fathers are viewed as noble or admirable while single mothers are viewed as having failed at providing an intact family environment for their children (Dejean, McGeorge, \& Carlson, 2012). Very little research has addressed attitudes toward single adoptive parents of different sexes. In fact, much of the literature available in regards to male adoptive parents focuses on gay men adopting within the context of a same-sex relationship or marriage instead of pursuing single fatherhood through adoption. The current investigation included the exploratory third hypothesis that participants would evaluate prospective adoptive parents differently based on their implied sex. 


\section{Method}

\subsection{Participants}

The convenience sample consisted of 556 adults. Some were recruited from college undergraduate psychology classes $(n=390)$ at a public university in the southern United States. Course sections from which participants were drawn ranged from 40 to 100 enrolled students and included both online and traditional courses. Students earned compensation in the form of course credit for their participation, and alternative studies and an assignment were available to students who were not desiring to participate or were ineligible for any of the current investigations. This study specified that participants must have been 18 years of age or older at the time of participation. The average age within the college student sample was $19.78(S D=2.31)$. There were more females in the college student sample $(74.42 \%)$, and the most endorsed racial classifications were White/Caucasian (72.06\%) and Black/African American (20.63\%).

Other participants were recruited online with Amazon Mechanical Turk (MTurk; $n=166$ ). MTurk participants were required to reside in the U.S. and be at least 18 years old. MTurk participants were compensated forty cents for completion of the study. Participants recruited via MTurk were older, on average, than those recruited through college classes $(M=36.53 ; S D=12.80)$. The MTurk sample included more male participants $(85.06 \%)$, and the most represented racial classification was White/Caucasian (81.29\%).

Out of the full sample of 556, 533 participants' data were complete for all included covariates, independent variables, and dependent variables, and were thus included in final analyses. When data were missing, it was because of skipped items and sections. The Institutional Review Board reviewed and approved this investigation before recruitment of both samples began.

\subsection{Measures}

\subsubsection{Demographic Information}

Participants completed closed-ended questions regarding their sex and race. In addition, this section included an open-ended item about age in years. Finally, participants reported on their religiosity using an ordinal scale from 1 (not at all religious) to 5 (extremely religious).

\subsubsection{Adoption Vignettes}

Participants were shown a typed description of either a woman named Lillian Jones or a man named Roger Jones having contacted an adoption agency in hopes of adopting a child. There were different versions of the vignette, differing by how the prospective adoptive parents' sex, marital status, and sexual orientation were implied: masculine name and single, feminine name and single, masculine name and married to a man (named Will), feminine name and married to a man, masculine name and married to a woman (referred to as Emily), and feminine name and married to a woman. All versions of the vignette depicted the prospective adoptive parent having cleared an extra room in the home and taking a class on child development. Furthermore, all versions specified that, if selected as an adoptive parent, this would be the prospective adoptive parent's first child.

\subsubsection{Expectations of Adoption Outcomes}

Participants were asked to imagine, based on nothing but the information offered in the vignette, how likely a variety of outcomes would be using a 9-point rating scale ranging from 1 (Not at all likely) to 9 (Extremely likely). This ten-item measure was partially adapted from one employed in a previous study on attitudes toward women undergoing intrauterine insemination to become pregnant (Sohr-Preston, Rohner, \& Lott, 2016), with some items created or amended for the current study. Item content and descriptive statistics are listed in Table 1. Items were averaged to create a single composite score for inclusion in final analyses. The authors selected averaging in place of summing items to maintain the scoring range of 1 (Not at all likely) to 9 (Extremely likely). The fact that the ten items in the scale displayed good internal consistency (Cronbach's $\alpha=.90$ ) supported creating a single score for this dependent variable. The average for the composite score was $6.93(S D=1.23)$. 
Table 1. Summary of descriptive statistics for individual items addressing expectations of adoption outcomes

\begin{tabular}{lllll}
\hline & $M$ & $S D$ & Min & Max \\
\hline This person will be excited about being a parent. & 8.13 & 1.37 & 1.00 & 9.00 \\
This person will be financially equipped for a new baby. & 6.64 & 1.71 & 1.00 & 9.00 \\
This person will be emotionally equipped for becoming a new parent. & 6.59 & 1.67 & 1.00 & 9.00 \\
This person's family and friends will welcome a new baby. & 6.90 & 1.71 & 1.00 & 9.00 \\
This person will exhibit warmth and sensitivity with a baby. & 7.47 & 1.54 & 1.00 & 9.00 \\
This person will be a good role model for a child. & 6.75 & 1.86 & 1.00 & 9.00 \\
A child adopted by this person will have a happy life. & 6.65 & 1.64 & 2.00 & 9.00 \\
A child adopted by this person will receive needed attention. & 7.09 & 1.76 & 1.00 & 9.00 \\
A child adopted by this person will receive needed guidance and life lessons. & 6.95 & 1.77 & 1.00 & 9.00 \\
$\begin{array}{l}\text { A child adopted by this person will develop healthy perceptions of romantic } \\
\text { relationships }\end{array}$ & 6.11 & 2.01 & 1.00 & 9.00 \\
\hline
\end{tabular}

Note. Scaling was from 1 (not at all likely) to 9 (extremely likely).

\subsubsection{Approval of Plans to Adopt}

Using a single item, participants reported on their overall approval of the described person's intent to adopt using a scale of 1 (Not at all supportive/Disapprove strongly) to 5 (Completely supportive/Strongly approve). Within the full sample, participants reported a mean approval rating of $4.12(S D=.99)$.

\subsubsection{Inferred Personal Characteristics of Prospective Adoptive Parent}

Participants then completed four items asking them to speculate about the prospective adoptive parent's personal characteristics, including the degree to which the prospective adoptive parent was likeable, responsible, selfish, and immoral. These items presented response options using a scale from 1 (Not at all) to 5 (Extremely). Overall, participants inferred higher responsibility $(M=4.18 ; S D=.82)$ and likeability $(M=3.94 ; S D=.79)$ than selfishness $(M=2.08 ; S D=91)$ and immorality $(M=2.10 ; S D=1.03)$.

\subsection{Procedure}

Data collection occurred online. Participants accessed the questionnaire via a weblink posted by the primary investigator on either the psychology department's participant recruitment site or MTurk. Immediately after accessing the survey, participants were randomly assigned to see one of the six vignette versions. Prior to viewing the vignette and subsequent follow-up questions, participants completed an informed consent page by indicating consent by typing their initials. Participants were mandated to complete the survey in one online session. Instructions specified that participants were permitted to skip any items or sections with which they felt discomfort.

\section{Results}

To examine hypothesized differences in expectations of adoption outcomes based on a prospective adoptive parent's sex, marital status, sexual orientation, and participant sex, the investigators conducted an analysis of covariance (ANCOVA) with three factor or grouping variables: participant sex (female or male), prospective adoptive parent implied sex (feminine name or masculine name), and marital description (single, married to a member of the opposite sex, or married to a member of the same sex). Self-reported level of religiosity was included as a covariate. The investigators examined the assumption of homogeneity of variances with Levene's test of equality of error variances. Results were not significant $(p=.46)$, suggesting the assumption had not been violated. However, the assumption of normality did appear to be violated based on significant Kolmogorov-Smirnov and Shapiro-Wilk tests and apparent negative skew (with scores clustered at higher values) in histograms. Since analysis of variance (ANOVA) procedures are widely considered robust to violations of the normality assumption, analyses proceeded but caution is recommended in interpreting results. 
Summarized in Table 2, neither the covariate of religiosity $(F=.75 ; p=.39)$ nor the main effect of the prospective adoptive parent's implied $\operatorname{sex}(F=.22 ; p=.64)$ were statistically significant, but the main effects of participant $\operatorname{sex}\left(F=16.22 ; p=.00\right.$; partial $\eta^{2}=.03$ or small effect size $)$ and marital description $(F=4.83 ; p=.01$; partial $\eta^{2}=.02$ or small effect size) were statistically significant. Post-hoc testing revealed that the ratings for single and married to a member of the same sex groups were significantly lower than those of the married to a member of the opposite sex group, but not significantly different from one another. Interaction effects were explored but were not significant $(p>.05)$.

Table 2. Results of ANCOVA examining differences in expectations of adoption outcomes

\begin{tabular}{|c|c|c|c|c|}
\hline Grouping Variable & $F$ & $p$ & partial $\eta^{2}$ & $M$ \\
\hline Religiosity (covariate) & .75 & .39 & .00 & \\
\hline Participant sex & 16.22 & .00 & .03 & \\
\hline Females & & & & 7.10 \\
\hline Males & & & & 6.69 \\
\hline Prospective parent's implied sex & .22 & .64 & .00 & \\
\hline Feminine name & & & & 6.93 \\
\hline Masculine name & & & & 6.84 \\
\hline Marital description & 4.83 & .01 & .02 & \\
\hline Single & & & & 6.77 \\
\hline Married to opposite sex & & & & 7.21 \\
\hline Married to same sex & & & & 6.86 \\
\hline
\end{tabular}

Next, the researchers examined potential differences in participants' overall approval of the described attempt to adopt and the inferred personal characteristics of the prospective adoptive parent. Specifically, the authors performed a multivariate analysis of covariance (MANCOVA) with five dependent variables (approval, likeability, responsibility, selfishness, immorality), three grouping variables or factors (participant sex, implied sex of prospective adoptive parent, and marital description), and the single covariate of religiosity. MANCOVA was conducted in place of a series of analyses of covariance (ANCOVA) due to significant correlations between all of the five dependent variables ( $r=-.34$ to $r=.58 ; p<.001$ for all pairings). The investigators examined the assumption of homogeneity of covariances with Box's test of equality of covariance matrices. Results were significant $(p=.02)$, suggesting the assumption had been violated. Beyond true inequality of covariances, Box's test is known to be sensitive to unequal cell sizes. The assumption of normality did again appear to be violated for all dependent variables based on significant Kolmogorov-Smirnov and Shapiro-Wilk tests and evident skew in histograms. Since analysis of variance (ANOVA) procedures are considered robust to violations of these assumptions, analyses proceeded as planned but caution is again called for.

As summarized in Table 3, the covariate of religiosity was statistically significant in this analysis (Wilks' $\Lambda$ $=.95 ; F=5.18 ; p=.00 ;$ partial $\eta^{2}=.05$ or small effect size), and all three main effects were significant. That is, the main effect of participant sex was significant (Wilks' $\Lambda=.96 ; F=5.02 ; p=.00$; partial $\eta^{2}=.04$ or small effect size), the main effect of marital description was statistically significant (Wilks' $\Lambda=.93 ; F=4.00 ; p=.00$; partial $\eta^{2}=.04$ or small effect size), and the main effect of the implied sex of the prospective adoptive parent was significant in this analysis (Wilks' $\Lambda=.97 ; F=3.07 ; p=.01$; partial $\eta^{2}=.03$ or small effect size). As with the previous analysis, interaction effects were explored but none were significant. 
Table 3. Results of MANCOVA examining ratings of approval of attempt to adopt, likeability, responsibility, selfishness, and immorality

\begin{tabular}{|c|c|c|c|c|c|c|c|c|}
\hline Grouping Variable & Wilks’ $\Lambda$ & $F$ & $p$ & $M(\mathrm{~A})$ & $M(\mathrm{~L})$ & $M(\mathrm{R})$ & $M(\mathrm{~S})$ & $M(\mathrm{I})$ \\
\hline Religiosity (covariate) & .95 & 5.18 & .00 & & & & & \\
\hline Participant sex & .96 & 4.61 & .00 & & & & & \\
\hline Females & & & & 4.24 & 4.04 & 4.28 & 1.95 & 2.09 \\
\hline Males & & & & 3.94 & 3.82 & 4.04 & 2.25 & 2.16 \\
\hline Prospective parent's implied sex & .97 & 3.07 & .01 & & & & & \\
\hline Feminine name & & & & 4.22 & 4.01 & 4.19 & 2.08 & 2.07 \\
\hline Masculine name & & & & 3.90 & 3.80 & 4.12 & 2.14 & 2.22 \\
\hline Marital description & .93 & 4.00 & .00 & & & & & \\
\hline Single & & & & 3.99 & 3.87 & 4.07 & 2.11 & 2.00 \\
\hline Married to opposite sex & & & & 4.39 & 4.08 & 4.37 & 1.98 & 1.82 \\
\hline Married to same sex & & & & 4.04 & 3.91 & 4.15 & 2.16 & 2.41 \\
\hline
\end{tabular}

Note. A = Approval; L = Likeability; $\mathrm{R}$ = Responsibility; $\mathrm{S}$ = Selfishness; I = Immorality.

Follow-up testing was conducted with a series of univariate ANCOVA. For the participant sex main effect, differences at the univariate level were significant for approval $\left(F=12.79 ; p=.00\right.$; partial $\eta^{2}=.02$ or small effect size), likeability $\left(F=10.76 ; p=.00 ;\right.$ partial $\eta^{2}=.02$ or small effect size $)$, responsibility $(F=11.26 ; p=.00$; partial $\eta^{2}=.02$ or small effect size), and selfishness $\left(F=13.22 ; p=.00\right.$; partial $\eta^{2}=.03$ or small effect size). Examination of the means (see Table 3 ) revealed that female participants rated the prospective adoptive parent more favorably than males did in these areas. The follow-up testing indicated that whether the prospective parent was presented with a masculine versus a feminine name and accompanying pronouns affected participants' approval of the attempt to adopt $\left(F=5.90 ; p=.02\right.$; partial $\eta^{2}=.01$ or small effect size $)$ and likeability $(F=5.35$; $p=.02$; partial $\eta^{2}=.01$ or small effect size). As seen in Table 3, ratings in theses area were higher, on average, when the prospective adoptive parent was presented with a feminine name. Regarding the main effect of marital description, ratings were significantly different for responsibility $\left(F=4.53 ; p=.01\right.$; partial $\eta^{2}=.02$ or small effect size) and immorality $\left(F=12.89 ; p=.00\right.$; partial $\eta^{2}=.05$ or small effect size). As seen in Table 3, prospective parents were rated as most responsible when in an opposite-sex marriage, and most immoral when in a same-sex marriage.

\section{Discussion}

\subsection{Summary of Findings}

This investigation aimed to detect bias, specifically bias against prospective adoptive parents stemming from an individual's sex, and the prospective parents' implied sex and marital situation (unmarried, married to a member of the opposite sex, or married to a member of the same sex). Using a vignette with multiple versions and self-report measures to assess attitudes and appraisals, results of this investigation did reveal evidence supporting bias in favor of prospective parents attempting to adopt if participating in a traditional male-female marriage. Female participants were more favorable in evaluating prospective adoptive parents. In addition, in some areas, prospective mothers were rated more favorably than prospective fathers. When presented with a description of a prospective parent making the exact same preparations (i.e., enrolling in a child development class and clearing a room in the home), while additionally described as either single or in a less traditional, same-sex marriage, participants rated the prospective adoptive parent as less prepared for parenting or less able to provide quality of life for a child. The observed mean differences suggest that participants in the current sample considered being single as a risk factor for less optimal parenting abilities by itself, and, with other factors kept the same, a single parent could not provide the same quality of life as one with an opposite-sex spouse. Having a second mother or father brought about no higher an average rating in overall expectations of adoption outcomes; perhaps not 
having been viewed as advantageous in any way, or perhaps seem as an additional barrier to nurturing parenting and a quality home environment. Participants may have believed, as many adults do, that all children need both a maternal and paternal influence in their formative years to develop adequately. On the other hand, some may have worried that having two parents of the same sex would indeed be detrimental to child development because of weaker moral guidance, lack of a model of heterosexual partnership, or teasing and discrimination directed at the family (see Meezan \& Rauch, 2005).

Prospective parents designated as single or in a same-sex marriage were also evaluated as significantly less responsible than those in an opposite-sex marriage. Once again, having a spouse emerged as advantageous in the perceptions of the participants, but only if the spouse was of the opposite sex. Such a finding suggests that entering a traditional husband-wife bond is viewed as a responsible act to a greater degree than remaining single or legally tying oneself to a member of the same sex. Alternatively, participants may have believed that seeking a parental role when not in a traditional union is inherently more irresponsible. Certainly, when prospective parents are seen as less responsible, it follows that expectations of their parenting abilities would be lower. Perhaps, when an adult has failed to choose what many view as the "grownup" option (i.e., marrying a member of the opposite sex), others assume they will continue to buck tradition or ignore societal norms regarding the parental role.

Marrying a member of the same sex may carry additional stigma in terms of being perceived as choosing a not only irresponsible but also immoral lifestyle. Being described as a member of a same-sex married couple indeed resulted in significantly higher perceptions of being immoral, further supporting prejudice against same-sex prospective parents. This finding was not surprising given previous arguments against same-sex relations as blatant violation of moral code present in popular religious tradition and education (e.g., Focus on the Family, 2015). Same-sex spouses, when pursuing adoption, may be hampered by the unshakeable stigma attached to them as inherently more immoral than other applicants despite their intentions, resources, and preparation for providing a loving, safe, and enriching home for a child.

Prospective adoptive parents may face further bias depending on the sex of any individual reviewing their case. That is, in the current sample, male participants were less positive in their perceptions of prospective parents' likeability, responsibility, and selfishness, regardless of prospective parents' personal characteristics. While the participants were not actually involved in a real adoption, these results suggest that male adoption agency personnel and biological fathers may harbor more negative views of adults seeking to adopt or hold applicants to higher standards. Past research has indicated males tend to deliver harsher evaluation of same-sex relations and same-sex parenting when compared to females (Costa et al., 2014; McCrary, 2014), suggesting this sex difference may be enhanced when dealing with same-sex prospective parents, though interaction effects were not supported in this investigation.

Little research has previously addressed bias against prospective parents rooted in parental sex. The results of the current study indicate that a prospective adoptive parent presented as female (i.e., with a traditionally feminine name and with feminine pronouns) was rated, on average, as significantly more likeable than a comparable prospective parent implied to be male. While this quality is not directly tied to ability to parent, likeability could contribute to a halo effect or general advantage when interactions are with a female versus male prospective parent. Fittingly, participants approved of the plan to adopt significantly less when the described applicant was described with a masculine name and masculine pronouns. This finding, especially given the lack of previous work to provide perspective, raises a number of questions. One question is whether choosing or entering into parenthood is seen as the domain of females, even in male-female couples. In addition, this result may fit with the widespread notion that mothers tend to be the "default parent" (see Blazoned, 2014), and fathers may be viewed as those supporting the default parent but generally adopt a secondary role in parenting. Further support stems from research on divorce indicating that fathers are usually assigned the role of non-residential parent and often must fight for custody when mothers' subsequent spouses petition to adopt children from the terminated marriage (Willemsen, Boccaccini, \& Pardini, 1999).

\subsection{Limitations and Directions for Future Research}

Consideration of the present findings requires acknowledgement of several noteworthy limitations. For example, recruitment was limited to the U.S., meaning results may not generalize to other geographic regions or cultural climates. In addition, the sample consisted of adults who will not necessarily be involved in adoption or know someone pursuing adoption. Results would have revealed more practical knowledge if the sample included government officials, adoption agency personnel, adoptive parents, or adopted individuals. 
Another relevant limitation is that effect sizes were small. Results, while statistically significant, involved lower levels of practical significance. In other words, the differences observed were not large enough to fall into qualitatively distinct categories. For variables exhibiting group differences, ratings still tended to fall within the same categorical descriptor (i.e., somewhat likely) even if some groups were notably lower on the specified scale.

The vignettes and the measures used to measure expectations of adoption outcomes and feelings toward the prospective parent were mostly newly created for this study, meaning further testing to more strongly establish reliability and validity is warranted. It may be interesting to attempt replication with different stimuli, such as an in-person meeting with or a video of a prospective adoptive parent describing personal desire to become a parent, the preparations made in anticipation of welcoming a new family member, and expectations for the future. Further studies should additionally extend examination of potential biases to rearing biological offspring (of at least one spouse for a same-sex marriage).

A final limitation is that the descriptor "single" simply implies lack of a legally recognized spouse. Many adults listed as single may be romantically connected to a man or a woman but not legally married to that individual, even if he or she enacts a parenting role or is somehow involved in child care. Similarly, a former romantic partner may continue to have contact with a single parent's adopted child after romantic relationship termination, whether as an involved but not legally recognized parental figure or as adoptive parent recognized later in a child's life. We cannot rule out that some participants made assumptions or held expectations about other adults not explicitly described in the vignette. Future replication should include two additional versions of the vignette featuring committed couples (opposite-sex and same-sex) hoping to become parents while not legally married to determine whether lacking a certified union yields different ratings. Alternatively, future studies may simply use the term "committed relationship" in place of "marriage".

\subsection{Implications}

While the findings of this investigation must be appraised while considering the above limitations, they suggest that adults pursuing adoption of a young child may be perceived as differently able to parent by government officials, agency and legal staff, and biological parents depending on their marital status, sexual orientation, own sex, and the sex of those evaluating them. This supported bias may not produce overt discrimination against prospective adoptive parents who are single, in a same-sex marriage, or male, but it may feed more covert negative attitudes toward adults seeking to become parents while not fitting the traditional mold of a woman serving as the main applicant while supported by her husband. These less obvious negative attitudes should not be disregarded as harmless since they may produce subtle disadvantage when prospective adoptive parents do not fit with stereotypes of traditional prospective parents. Further negative consequences may come about when such biases allow family and friends of prospective adoptive parents to provide less support when the adoption process proves long or disappointing. Adopting may prove particularly stressful for same-sex couples because they are forced to put their sexuality on display (see Goldberg \& Smith, 2011). Single prospective parents, too, may call attention to their single status when attempting to transition to a parental role. Adults in the U.S. currently have considerable options for becoming parents beyond biological parenthood resulting from heterosexual relations within the context of an opposite-sex marriage. Taking advantage of the option to pursue adoption, though, may be less often stressful, awkward, embarrassing or intrusive when married women with male spouses initiate such pursuits. Given past evidence that mental health may improve during the transition to parenthood in regions more supportive of less traditional parents (Goldberg \& Smith, 2011), it is imperative that more researchers target attitudes toward parents in a variety of marital or relationship situations and of both sexes. Increased understanding of the additional stressors potentially faced by certain prospective parents is clearly warranted among mental health personnel, government officials, and adoption agency personnel.

\section{References}

Adams, J., \& Light, R. (2015). Scientific consensus, the law, and same sex parenting outcomes. Social Science Research, 53, 300-310. https://doi.org/10.1016/j.ssresearch.2015.06.008

Adoption. (2016, May 19). Retrieved from https://www.law.cornell.edu/wex/adoption

Andersen, M. L. (1991). Feminism and the American family ideal. Journal of Comparative Family Studies, 235-246.

Anderssen, N., Amlie, C., \& Ytterøy, E. A. (2002). Outcomes for children with lesbian or gay parents. A review of studies from 1978 to 2000. Scandinavian Journal of Psychology, 43, 335-351. https://doi.org/10.1111/1467-9450.00302 
Barbash, F. (2016, April 1). Federal judge voids Mississippi ban on same-sex couple adoptions. The Washington Post. Retrieved from https://www.washingtonpost.com/news/morning-mix/wp/2016/04/01/federal-judge-voids-mississippi-ban-o n-same-sex-couple-adoptions/

Bennett, M., \& Jamieson, L. (1999). Perceptions of parents as a function of their marital status and sex. Infant $\begin{array}{llll}\text { and Child } & \text { Development, } & \text { 149-154. }\end{array}$ https://doi.org/10.1002/(SICI)1522-7219(199909)8:3\%3C149::AID-ICD196\%3E3.0.CO;2-5

Berry, M., Barth, R. P., \& Needell, B. (1996). Preparation, support, and satisfaction of adoptive families in agency and independent adoptions. Child and Adolescent Social Work Journal, 13, 157-183. https://doi.org/10.1007/BF01876644

Biblarz, T. J., \& Stacey, J. (2010). Ideal families and social science ideals. Journal of Marriage and Family, 72, 41-44. https://doi.org/10.1111/j.1741-3737.2009.00682.x

Blazoned, M. (2014, October 28). The default parent. The Huffington Post. Retrieved from http://www.huffingtonpost.com/m-blazoned/the-default-parent_b_6031128.html

Bos, H. M., Van Balen, F., \& Van den Boom, D. C. (2007). Child adjustment and parenting in planned $\begin{array}{lllll}\text { lesbian-parent families. American Journal of Orthopsychiatry, } & \text { 77, } 38 .\end{array}$ https://doi.org/10.1037/0002-9432.77.1.38

Brodzinsky, D. M., \& the staff of the Evan B. Donaldson Adoption Institute. (2003). Adoption by lesbians and gays: A national survey of adoption agency policies, practices, and attitudes. New York, NY: Evan B. Donaldson Adoption Institute.

Brown, S., Smalling, S., Groza, V., \& Ryan, S. (2009). The experiences of gay men and lesbians in becoming and being adoptive parents. Adoption Quarterly, 12, 229-246. https://doi.org/10.1080/10926750903313294

Child Welfare Information Gateway. (2012). Who may adopt, be adopted, or place a child for adoption? Retrieved from https://www.childwelfare.gov/pubPDFs/parties.pdf

Children of All Nations. (2016). Singles adoption. Retrieved from http://childrenofallnations.com/adoption-programs/singles-adoption/

Costa, P. A., Almeida, R., Anselmo, C., Ferreira, A., Pereira, H., \& Leal, I. (2014). University students' attitudes toward same-sex parenting and gay and lesbian rights in Portugal. Journal of Homosexuality, 61, 1667-1686. https://doi.org/10.1080/00918369.2014.951253

Daniluk, J. C., \& Hurtig-Mitchell, J. (2003). Themes of hope and healing: Infertile couples' experiences of $\begin{array}{llllll}\text { adoption. Journal of Counseling and Development, } & 81, & 389 .\end{array}$ https://doi.org/10.1002/j.1556-6678.2003.tb00265.x

DeJean, S. L., McGeorge, C. R., \& Carlson, T. S. (2012). Attitudes toward never-married single mothers and fathers: Does gender matter? Journal of Feminist Family Therapy, 24, 121-138. https://doi.org/10.1080/08952833.2012.648121

Dunn, J., Deater-Deckard, K., Pickering, K., O’Connor, T. G., Golding, J., \& The ALSPAC Study Team. (1998). Children's adjustment and prosocial behaviour in step-, single-parent, and non-stepfamily settings: Findings from a community study. Journal of Child Psychology and Psychiatry, and Allied Disciplines, 39, 1083-1095. https://doi.org/10.1111/1469-7610.00413

Ethics Committee of the American Society for Reproductive Medicine. (2013). Access to fertility treatment by gays, lesbians, and unmarried persons: A committee opinion. Fertility and Sterility, 100, 1524-1527. https://doi.org/10.1016/j.fertnstert.2013.08.042

Fisher, A. P. (2003). Still "not quite as good as having your own"? Toward a sociology of adoption. Annual Review of Sociology, 29, 335-361. https://doi.org/10.1146/annurev.soc.29.010202.100209

Focus on the Family. (2015). What does the bible say about homosexuality? Retrieved from http://www.focusonthefamily.com/socialissues/sexuality/homosexuality-theology-and-the-church/what-doe s-the-bible-say-about-homosexuality

Gartrell, N., Deck, A., Rodas, C., Peyser, H., \& Banks, A. (2005). The national lesbian family study: 4. Interviews with the 10-year-old children. American Journal of Orthopsychiatry, 75, 518-524. https://doi.org/10.1037/0002-9432.75.4.518 
Gates, G. J., Badgett, M. V., Macomber, J. E., \& Chambers, K. (2007). Adoption and foster care by gay and lesbian parents in the United States. The Williams Institute. Retrieved from https://escholarship.org/uc/item/2v4528cx\#page-3

Goldberg, A. E., \& Smith, J. Z. (2011). Stigma, social context, and mental health: Lesbian and gay couples across the transition to adoptive parenthood. Journal of Counseling Psychology, 58, 139. https://doi.org/10.1037/a0021684

Goldberg, A. E., Downing, J. B., \& Sauck, C. C. (2007). Choices, challenges, and tensions: Perspectives of lesbian prospective adoptive parents. Adoption Quarterly, 10, 33-64. https://doi.org/10.1300/J145v10n02_02

Golombok, S., Perry, B., Burston, A., Murray, C., Mooney-Somers, J., Stevens, M., \& Golding, J. (2003). Children with lesbian parents: A community study. Developmental Psychology, 39, 20-33. https://doi.org/10.1037/0012-1649.39.1.20

Golombok, S., Tasker, F., \& Murray, C. (1997). Children raised in fatherless families from infancy: Family relationships and the socioemotional development of children of lesbian and single heterosexual mothers. $\begin{array}{llllll}\text { Journal of Child Psychology and Psychiatry, 38, } & \text { 783-791. }\end{array}$ https://doi.org/10.1111/j.1469-7610.1997.tb01596.x

Golombok, S., Zadeh, S., Imrie, S., Smith, V., \& Freeman, T. (2016). Single mothers by choice: Mother-child relationships and children's psychological adjustment. Journal of Family Psychology, 30, 409. https://doi.org/10.1037/fam0000188

Groze, V. (1991). Adoption and single parents: A review. Child Welfare: Journal of Policy, Practice, and Program, 70, 321-332.

Ifcher, J., \& Zarghamee, H. (2014). The happiness of single mothers: Evidence from the General Social Survey. Journal of Happiness Studies, 15, 1219-1238. https://doi.org/10.1007/s10902-013-9472-5

Jadva, V., Badger, S., Morrissette, M., \& Golombok, S. (2009). Mom by choice, single by life's circumstance...' Findings from a large scale survey of the experiences of single mothers by choice. Human Fertility, 12, 175-184. https://doi.org/10.3109/14647270903373867

Jeter, K. (1995). From stereotype to archetype: Single parent families. Marriage \& Family Review, 20, 533-550. https://doi.org/10.1300/J002v20n03_12

Kreider, R. M., \& Lofquist, D. A. (2010). Adopted children and stepchildren: 2010. Adoption Quarterly, 13, 268-291.

Lifelong Adoptions. (2017). LGBT Adoption Laws. Retrieved from http://www.lifelongadoptions.com/lgbt-adoption-resources/lgbt-adoption-laws

MacCallum, F., \& Golombok, S. (2004). Children raised in fatherless families from infancy: A follow-up of children of lesbian and single heterosexual mothers at early adolescence. Journal of Child Psychology and Psychiatry, 45, 1407-1419. https://doi.org/10.1111/j.1469-7610.2004.00324.x

Markus, E., Weingarten, A., Duplessi, Y., \& Jones, J. (2010). Lesbian couples seeking pregnancy with donor insemination. Journal of Midwifery \& Women's Health, 55, 124-132. https://doi.org/10.1016/j.jmwh.2009.09.014

McCrary, D. G. (2014). A study of homophobia among HBCU undergraduate students toward gay and lesbian adoption. American Journal of Sexuality Education, 9, 257. https://doi.org/10.1080/15546128.2014.916645

McLanahan, S., \& Sandefur, G. (1994). Growing up with a single parent: What hurts, what helps. Cambridge: Harvard University Press.

Meezan, W., \& Rauch, J. (2005). Gay marriage, same-sex parenting, and America's children. The Future of Children, 15, 97-113. https://doi.org/10.1353/foc.2005.0018

Miall, C. E. (1987). The stigma of adoptive parent status: Perceptions of community attitudes toward adoption and the experience of informal social sanctioning. Family Relations, 36, 34-39. https://doi.org/10.2307/584644

Monama, D. D. (2009). Single parent families: From stereotype to archetype (Unpublished doctoral dissertation). University of South Africa, Pretoria, Gauteng, South Africa. 
Moyer, J. W. (2015, November 12). Utah judge removes lesbian couple's foster child, says she'll be better off with heterosexuals. The Washington Post. Retrieved from https://www.washingtonpost.com/news/morning-mix/wp/2015/11/12/utah-judge-removes-foster-child-from -lesbian-couple-saying-shell-be-better-off-with-heterosexuals/

Pakizegi, B. (1990). Emerging family forms: Single mothers by choice: Demographic and psychosocial variables. Maternal-Child Nursing Journal, 19, 1-19.

Patterson, C. J. (2006). Children of lesbian and gay parents. Current Directions in Psychological Science, 15, 241-244. https://doi.org/10.1111/j.1467-8721.2006.00444.x

Pennington, J., \& Knight, T. (2011). Through the lens of hetero-normative assumptions: Re-thinking attitudes towards gay parenting. Culture, Health \& Sexuality, 13, 59-72. https://doi.org/10.1080/13691058.2010.519049

Perrin, E. C. (2013, March). AAP policy: No relationship between parents' sexual orientation and children's well-being. American Academy of Pediatrics News, 34. Retrieved from http://aapnews.aappublications.org/content/early/2013/03/21/aapnews.20130321-1.full. pdf + html

Perrin, E. C., \& Committee on Psychosocial Aspects of Child and Family Health. (2002). Technical report: Coparent or second-parent adoption by same-sex parents. Pediatrics, 109, 341-344. https://doi.org/10.1542/peds.109.2.341

Raleigh, E. (2012). Are same-sex and single adoptive parents more likely to adopt transracially? A national analysis of race, family structure, and the adoption marketplace. Sociological Perspectives, 55, 449-471. https://doi.org/10.1525/sop.2012.55.3.449

Ressler, R. W., Smith, C., Cavanagh, S., \& Crosnoe, R. (2017). Mothers' union statuses and their involvement in young children's schooling. Journal of Marriage and Family, 79, 94-109. https://doi.org/10.1111/jomf.12374

Robinson, B. E. (1997). Birds do it. Bees do it. So why not single women and lesbians? Bioethics, 11, 217-227. https://doi.org/10.1111/1467-8519.00060

Ross, L. E., Epstein, R., Anderson, S., \& Eady, A. (2009). Policy, practice, and personal narratives: Experiences of LGBTQ people with adoption in Ontario, Canada. Adoption Quarterly, 12, 272-293. https://doi.org/10.1080/10926750903313302

Ryan, S. D., Pearlmutter, S., \& Groza, V. (2004). Coming out of the closet: Opening agencies to gay and lesbian adoptive parents. Social Work, 49, 85-95. https://doi.org/10.1093/sw/49.1.85

Shireman, J. F. (1994). Adoptions by single parents. Marriage \& Family Review, 20, 367-388. https://doi.org/10.1300/J002v20n03_04

Sohr-Preston, S. L., Rohner, A. K., \& Lott, B. H. (2016). Southern American university undergraduates' attitudes toward intrauterine insemination undertaken by women of differing age, marital status and sexual orientation. Journal of International Women's Studies, 17, 49-66. Retrieved from http://vc.bridgew.edu/jiws/vol17/iss4/4

Stacey, J., \& Biblarz, T. J. (2001). (How) does the sexual orientation of parents matter? American Sociological Review, 66, 159-183. https://doi.org/10.2307/2657413

Tan, T. X. (2004). Child adjustment of single-parent adoption from China: A comparative study. Adoption Quarterly, 8, 1-20. https://doi.org/10.1300/J145v08n01_01

Tasker, F. (2005). Lesbian mothers, gay fathers, and their children: A review. Journal of Developmental \& Behavioral Pediatrics, 26, 224-240. https://doi.org/10.1097/00004703-200506000-00012

Tasker, F., \& Golombok, S. (1998). The role of co-mothers in planned lesbian-led families. Journal of Lesbian Studies, 2, 49-68. https://doi.org/10.1300/J155v02n04_05

The National Infertility \& Adoption Education Nonprofit. (2015). Cost of Adoption in the US. Retrieved from https://creatingafamily.org/adoption/resources/cost-adoption-us/

United States Census Bureau. (2011, September 27). Census bureau releases estimates of same-sex married couples. Retrieved from http://www.census.gov/newsroom/releases/archives/2010_census/cb11-cn181.html 
Vanfraussen, K., Ponjaert-Kristoffersen, I., \& Brewaeys, A. (2003). Family functioning in lesbian families created by donor insemination. American Journal of Orthopsychiatry, 73, 78-90. https://doi.org/10.1037/0002-9432.73.1.78

Vespa, J., Lewis, J. M., \& Kreider, R. M. (2013). America's families and living arrangements: 2012. Current Population Reports, 20-570.

Wainright, J. L., \& Patterson, C. J. (2006). Delinquency, victimization, and substance use among adolescents with female same-sex parents. Journal of Family Psychology, 20, 526-530. https://doi.org/10.1037/0893-3200.20.3.526

Wegar, K. (2000). Adoption, family ideology, and social stigma: Bias in community attitudes, adoption research, and practice. Family Relations, 49, 363-369. https://doi.org/10.1111/j.1741-3729.2000.00363.x

Willemsen, E. W., Boccaccini, M., \& Pardini, D. (1999). Factors influencing custody decisions in contested adoption cases. Child and Adolescent Social Work Journal, 16, 127-147. https://doi.org/10.1023/A:1022361407713

Williams, K., Sassler, S., Frech, A., Addo, F., \& Cooksey, E. (2013). Mothers' union histories and the mental and physical health of adolescents born to unmarried mothers. Journal of Health and Social Behavior, 54, 278-295. https://doi.org/10.1177/0022146513497034

\section{Copyrights}

Copyright for this article is retained by the author(s), with first publication rights granted to the journal.

This is an open-access article distributed under the terms and conditions of the Creative Commons Attribution license (http://creativecommons.org/licenses/by/4.0/). 